\title{
Echokardiograficzna manifestacja infekcyjnego zapalenia wsierdzia u zdrowego kardiologicznie dziecka
}

\author{
The echocardiographic demonstration of the infective endocarditis \\ in a cardiologically healthy child
}

\author{
Anna Wałdoch, Joanna Kwiatkowska \\ Katedra i Klinika Kardiologii Dziecięcej i Wad Wrodzonych Serca Gdańskiego Uniwersytetu Medycznego
}

\begin{abstract}
Streszczenie
Infekcyjne zapalenie wsierdzia należy obecnie do jednej z rzadziej rozpoznawanych jednostek chorobowych w populacji dziecięcej. W grupie ryzyka pozostają pacjenci z wrodzonymi wadami serca przed leczeniem interwencyjnym i operacyjnym lub po nim. Poniżej przedstawiono nietypowy przypadek infekcyjnego zapalenia wsierdzia zastawki mitralnej, o etiologii Staphylococcus aureus, u dotychczas zdrowego 11-letniego chłopca.
\end{abstract}

Słowa kluczowe: echokardiografia, infekcyjne zapalenie wsierdzia, zdrowe dziecko, gronkowiec złocisty

(Folia Cardiologica 2015; 10, 4: 294-296)

\begin{abstract}
Wstęp
Infekcyjne zapalenie wsierdzia to obecnie jedna z rzadziej rozpoznawanych jednostek chorobowych w populacji dziecięcej. Uważa się, że częstość jej występowania istotnie wzrasta z wiekiem pacjenta i dotyczy głównie osób starszych oraz obciążonych wywiadem kardiologiczno-kardiochirurgicznym. Zmienia się także etiologia zakażeń - coraz mniejszą rolę odgrywają paciorkowce jamy ustnej, a większą gronkowce, zwłaszcza Staphylococcus aureus. Mimo postępu wiedzy choroba ta nadal jest obarczona wysoką śmiertelnością z powodu swojego zróżnicowanego obrazu klinicznego, wielonarządowej manifestacji oraz zmieniającego się profilu epidemiologicznego.
\end{abstract}

\section{Opis przypadku}

Chłopiec w wieku 11 lat, dotychczas nieobciążony wywiadem kardiologicznym, został przyjęty do kliniki ze szpitala powiatowego z podejrzeniem infekcyjnego zapalenia wsierdzia. W wywiadzie stwierdzono niewielki uraz prawego podudzia, do którego doszło około 2 tygodnie przed przyjęciem na oddział pediatryczny, niewymagający interwencji medycznej. Po upływie 2 tygodni nagle wystąpiła gorączka do $40^{\circ} \mathrm{C}$ z cechami zapalenia gardła, a w badaniu przedmiotowym stwierdzono po raz pierwszy szmer skurczowy nad sercem, powiększenie wątroby (ok. $3 \mathrm{~cm}$ poniżej łuku żebrowego) oraz zmianę o charakterze rumieniowym z nadżerką w części centralnej na prawym podudziu. Ze względu na wysokie stężenia parametrów stanu zapalnego (białko C-reaktywne [CRP, C-reactive protein] - $188 \mathrm{mg} / \mathrm{dl}$, prokalcytonina - $30 \mathrm{ng} / \mathrm{ml}$ ) włączono empiryczną antybiotykoterapię (cefotaksym), którą zmodyfikowano według antybiogramu (dołączając klindamycynę) po uzyskaniu dodatnich posiewów krwi, płynu mózgowo-rdzeniowego oraz wymazu z rany podudzia w kierunku Staphylococcus aureus. Mimo istotnego obniżenia wykładników stanu zapalnego stan dziecka nadal oceniano jako średni, ponadto niepokój budził ponowny wzrost ciepłoty ciała do $39-39,5^{\circ} \mathrm{C}$ z towarzyszącymi dreszczami, przy całkowicie zagojonej ranie podudzia i nadal dodatnich posiewach krwi w kierunku Staphylococcus aureus i ujem-

Adres do korespondencji: dr n. med. Anna Wałdoch, Katedra i Klinika Kardiologii Dziecięcej i Wad Wrodzonych Serca, Gdański Uniwersytet Medyczny, ul. Dębinki 7, 80-952 Gdańsk, tel. 5834928 82, faks 5834928 95, e-mail: anna.waldoch@gumed.edu.pl 


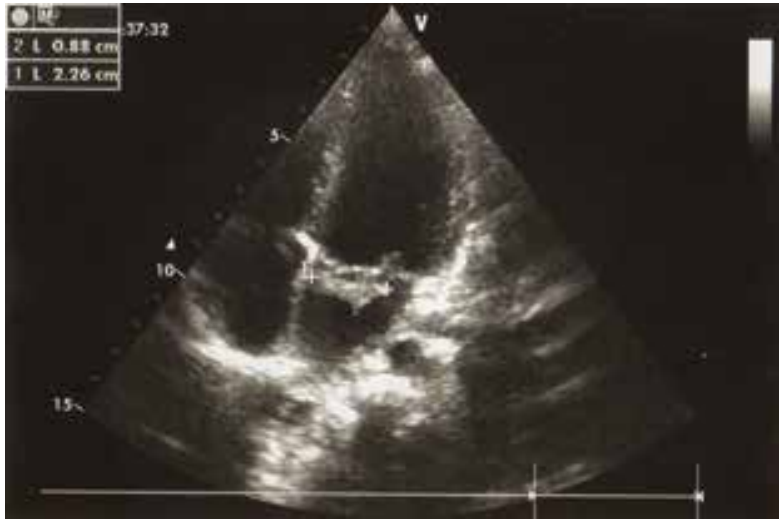

Rycina 1. Badanie echokardiograficzne: projekcja czterojamowa ogromna wegetacja w jamie lewego przedsionka, uszypułowana na płatku przednim zastawki mitralnej

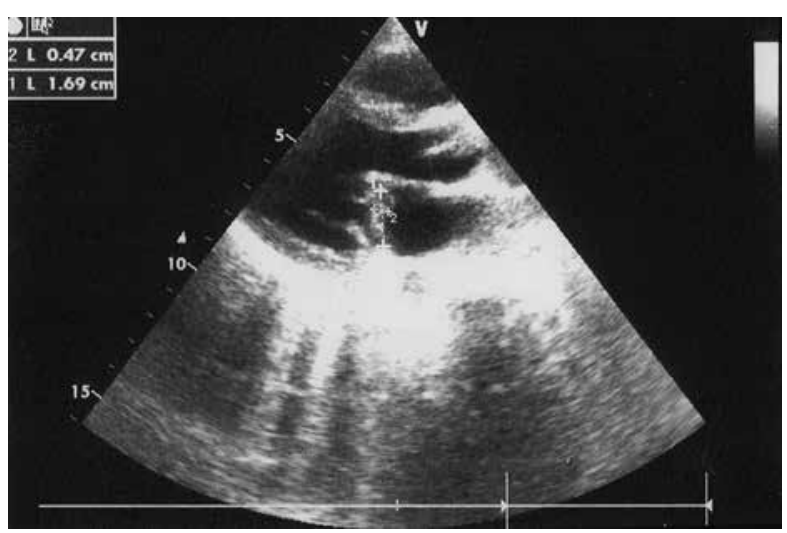

Rycina 2. Badanie echokardiograficzne: projekcja przymostkowa - widoczna wegetacja w jamie lewego przedsionka nieznacznie wpuklająca się w ujście otwartej zastawki mitralnej

nym posiewie z płynu mózgowo-rdzeniowego. Po włączeniu meropenemu wykonano badanie echokardiograficzne, w którym nie stwierdzono żadnych odchyleń. W kolejnych dobach hospitalizacji obserwowano systematyczną poprawę stanu ogólnego pacjenta, ale mimo niemal całkowitej normalizacji parametrów stanu zapalnego (CRP $-5 \mathrm{mg} / \mathrm{dl}$, prokalcytonina $-0,3 \mathrm{ng} / \mathrm{ml}$ ) utrzymywały się stany podgorączkowe oraz wystąpiło grubopłatowe łuszczenie naskórka palców dłoni i stóp, współistniejące z drobnoplamistą wysypką, głównie na skórze tułowia. Zważywszy na obraz echokardiograficzny, sugerujący obecność wegetacji na zastawce mitralnej, przekazano chłopca do Kliniki Kardiologii Dziecięcej i Wad Wrodzonych Serca Gdańskiego Uniwersytetu Medycznego. W dniu przyjęcia dziecko było w średnim stanie ogólnym (rytm serca - 86/min, saturacja - 98\%); w badaniu sposród odchyleń stwierdzono szmer skurczowy nad sercem 3/6 w skali Levine'a, hepatosplenomegalię oraz wyżej opisane zmiany skórne. $W$ badaniu echokardiograficznym zobrazowano wegetacje uszypułowaną głównie na płatku przednim o wymiarach

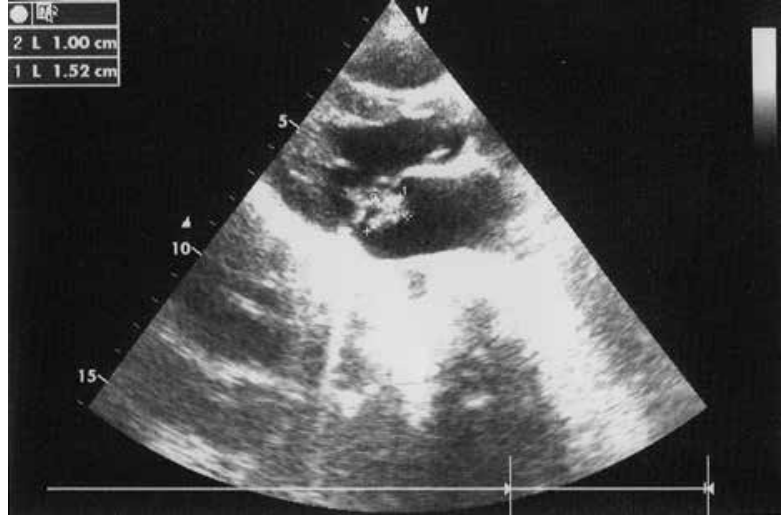

Rycina 3. Badanie echokardiograficzne: zmodyfikowana projekcja czterojamowa prezentująca największy wymiar wegetacji na zastawce mitralnej

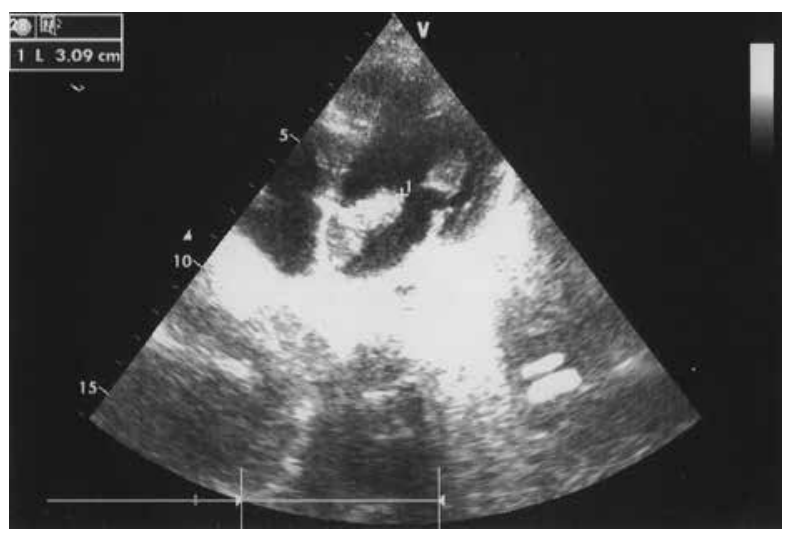

Rycina 4. Badanie echokardiograficzne: projekcja przymostkowa widoczna wegetacja $\mathrm{w}$ jamie lewego przedsionka $\mathrm{w}$ fazie skurczu komory lewej

$22 \mathrm{~mm} \times 8,8 \mathrm{~mm}$, balotującą do światła zastawki mitralnej. Nie zarejestrowano istotnego utrudnienia napływu do lewej komory, a jedynie niewielką niedomykalność zastawki, przy zachowanej prawidłowej kurczliwości jam serca (ryc. 1-4). Zmodyfikowano dotychczasową antybiotykoterapię, włączając wankomycynę i gentamycynę, oraz skonsultowano pacjenta kardiochirurgicznie. Ze względu na niespotykanie duży wymiar wegetacji oraz wysokie ryzyko powikłań zatorowych zdecydowano o usunięciu jej chirurgicznie w trybie pilnym i kontynuacji dotychczasowego leczenia zachowawczego. W 15. dobie od wystąpienia pierwszych objawów wykonano skuteczną rekonstrukcję zastawki mitralnej. W aktualnym badaniu echokardiograficznym utrzymuje się jedynie niewielka niedomykalność zastawki dwudzielnej.

\section{Podsumowanie}

Infekcyjne zapalenie wsierdzia jest obecnie chorobą rzadką, zwłaszcza w populacji dziecięcej. Okazuje się jednak, że 
może dojść do rozwoju ogromnej wegetacji, nawet u zdrowego dziecka, u którego nie wykonywano dotychczas żadnych interwencji medycznych.

\section{Konflikt interesów}

Autorki nie zgłaszają konfliktu interesów.

\section{Abstract}

Infective endocarditis is now one of the less recognized disease entities in the pediatric population. In the risk group there are patients with congenital heart defects before or after intervention and surgery treatment. We present an unusual case of the infective endocarditis of the mitral valve, with the etiology of Staphylococcus aureus, in previously healthy 11-year-old boy.

Key words: echocardiography, infective endocarditis, healthy child, Staphylococcus aureus

(Folia Cardiologica 2015; 10, 4: 294-296)

\section{Komentarz}

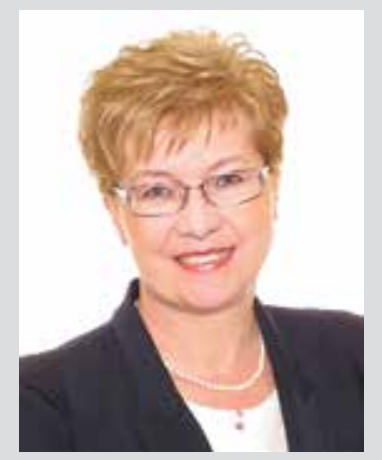

\section{prof. dr hab. n. med. Bożena Werner}

Klinika Kardiologii Wieku Dziecięcego i Pediatrii Ogólnej

Warszawskiego Uniwersytetu Medycznego

Infekcyjne zapalenie wsierdzia (IZW) jest zakażeniem obejmującym śródbłonek wyściełający serca, przede wszystkim zastawki. Historycznie do zachorowania predysponują wrodzone i nabyte wady serca, a zwłaszcza wszczepione sztuczne zastawki i inne sztuczne materiały.

Jednak w ostatnich 25 latach w krajach wysoko uprzemysłowionych notuje się znaczny wzrost liczby zachorowań na zapalenie wsierdzia u pacjentów bez wcześniejszej wady serca. W materiale opracowanym przez Castillo i wsp. [1] wśród 240 pacjentów z zapaleniem wsierdzia na własnych zastawkach aż w 104 przypadkach (prawie 50\%) choroba dotyczyła osób bez wady serca. Wymienieni badacze porównali przebieg choroby u pacjentów bez wcześniejszej wady serca w latach 1987-2000 i w latach 2001-2013, stwierdzając, że w ostatnim okresie przebieg choroby jest cięższy, obserwuje się wegetacje większych rozmiarów oraz więcej powikłań. Zwiększyły się śmiertelność i częstość interwencji kardiochirurgicznych w tej grupie chorych. Wyniki te są zgodne z wynikami prospektywnego badania, obejmującego 945 przypadków IZW, spośród których 435 dotyczyło własnych zastawek lewego serca, w tym 173 wyjściowo prawidłowych i 262 z wadą [2]. Niewydolność serca, wstrząs septyczny czy konieczność operacji kardiochirurgicznej statystyczne częściej dotyczyły pacjentów bez uprzedniej wady serca, co skutkowało gorszym rokowaniem. W obu badaniach u pacjentów bez wady serca częściej stwierdzano obecność wegetacji w badaniu echokardiograficznym, a także rozmiary wegetacji były u nich większe.

Publikacje dotyczące populacji pediatrycznej są nieliczne. Marom i wsp. [3] opisali 51 przypadków IZW w latach 1992-2004, w tym 9 (18\%) u zdrowych dzieci, które nie miały ani wady serca, ani nie były obciążone żadnym predysponującym czynnikiem. Przebieg kliniczny choroby u tych bez wady charakteryzował się wysoką gorączką, niewydolnością serca i powikłaniami zatorowymi związanymi z dużymi wegetacjami. Na podkreślenie zasługuje wysoka częstość (80\%) leczenia kardiochirurgicznego w trybie pilnym, w ostrym okresie choroby. Z kolei Ware i wsp. [4] przenalizowali przebieg IZW u 1033 dzieci leczonych w 37 ośrodkach w okresie od 1997 do 2010 roku. W grupie tej u 663 stwierdzono wcześniej chorobę serca, a 370 było zdrowych. U dzieci bez wady serca stwierdzono większą częstość występowania zatorów związanych z dużymi wegetacjami. Natomiast częstość interwencji chirurgicznych u dzieci wyjściowo z wadą serca była większa i wynosiła 18\%, natomiast u dzieci uprzednio zdrowych - 10\%. Śmiertelność była 2-ukrotnie wyższa w grupie z patologią serca i wynosiła7\% w porównaniu z 3,5\% u dzieci bez wady serca. W piśmiennictwie nie ma aktualnych opracowań dotyczących zapalenia wsierdzia w populacji polskich dzieci. W badaniu mojego współautorstwa, 
opublikowanym w 2007 roku, wśród 39 dzieci z IZW tylko troje było kardiologicznie zdrowych przed tym epizodem [5]. Obecnie w klinice, którą kieruję, liczba takich przypadków się zwiększyła.

Ostatnio zwraca się uwagę na wzrost liczby zakażeń gronkowcowych w etiologii IZW u dzieci [6, 7]. W odniesieniu do najczęstszej etiologii IZW u pacjentów bez wady serca doniesienia są rozbieżne. U pacjentów analizowanych przez Olmos i wsp. [2] najczęściej izolowanymi patogenami były Staphylococcus aureus i Streptococcus bovis, natomiast w grupie opisanej przez Castillo i wsp. [1] w okresie 2001-2013 przeważały paciorkowce zieleniące.

Infekcyjne zapalenie wsierdzia jest ciężkim powikłaniem bakteriemii Staphylococcus aureus. W analizie przeprowadzonej przez Palraj i wsp. [8] powikłanie to dotyczyło 85 (13\%) spośród 678 pacjentów z bakteriemią wywołaną gronkowcem złocistym i występowało w okresie do 12 tygodni od zakażenia. Kluczową rolę w rozpoznaniu IZW u pacjentów z bakteriemią odgrywa echokardiografia. Cytowani autorzy opracowali strategię przesiewowego badania echokardiograficznego u pacjentów z bakteriemią gronkowcową.

Ważnym zagadnieniem jest leczenie farmakologiczne zapalenia wsierdzia o etiologii gronkowcowej. Zagadnienie to dokładnie omówiono w wytycznych Europejskiego Towarzystwa Kardiologicznego [9]. W przypadku zakażeń zastawek własnych wywołanych gronkowcem złocistym wrażliwym na metycylinę zaleca się oksacylinę lub kloksacylinę. Leczenie skojarzone gentamycyną jest opcjonalne, gdyż nie udowodniono korzyści z dołączenia aminoglikozydu w zakażeniach gronkowcowych. Zarówno w przypadku bakteriemii, jak i zapalenia wsierdzia gronkowcem metycylinoopornym rekomendowanym antybiotykiem jest wankomycyna. W zapaleniu wsierdzia w obrębie własnych zastawek opcjonalne jest dołączenie gentamycyny w pierwszych 3-5 dniach leczenia. Problemem terapeutycznym w ostatnich latach stają się zakażenia gronkowcowe szczepami opornymi na wankomycynę [10].

Praca „Echokardiograficzna manifestacja infekcyjnego zapalenia wsierdzia u zdrowego kardiologicznie dziecka” zwraca uwagę na fakt, że IZW może wystąić u dziecka bez predysponującej choroby serca. Źródłem zakażenia w tym przypadku była najprawdopodobniej niewielka rana podudzia. Długo utrzymująca się bakteriemia gronkowcowa doprowadziła do zapalenia wsierdzia u pacjenta ze zdrowym sercem. Rozpoznanie ustalono po zobrazowaniu dużych rozmiarów wegetacji w badaniu echokardiograficznym. Zastosowane leczenie kardiochirurgiczne zapobiegło powikłaniom zatorowym. Przedstawiony przez autorów przypadek wpisuje się w aktualną charakterystykę przebiegu tej choroby u pacjentów bez wady serca - zarówno pod względem obrazu klinicznego, jak i echokardiograficznego.

\section{Piśmiennictwo}

1. Castillo F.J., Anguita M., Castillo J.C. i wsp. Changes in clinical profile, epidemiology and prognosis of left-sided native-valve infective endocarditis without predisposing heart condition. Rev. Esp. Cardiol. 2015; 68: 445-448.

2. Olmos C., Vilacosta I., Fernandez C. i wsp. Comparison of clinical features of left-sided infective endocarditis involving previously normal versus previously abnormal valves. Am. J. Cardiol. 2014; 114: 278-283.

3. Marom D., Ashkenazi S., Samra Z., Birk E. Infective endocarditis in previously healthy children with structurally normal hearts. Pediatr. Cardiol. 2013; 34: 1415-1421.

4. Ware A.L., Tani L.Y., Weng H.Y. i wsp. Resource utilization and outcomes of infective endocarditis in children. J. Pediatr. 2014; 165: 807-812e.

5. Werner B., Wróblewska-Kałużewska M., Kucińska B., Wójcicka-Urbańska B. Kliniczne i terapeutyczne aspekty zapalenia wsierdzia u dzieci. Med. Wieku Rozw. 2007; 11: 159-165.

6. Day M.D., Gauvreau K., Shulman S., Newburger J.W. Characteristics of children hospitalized with infective endocarditis. Circulation 2009; 119: 865-870.
7. Alshammary A., Hervas-Malo M., Robinson J.L. Pediatric infective endocarditis: has Staphylococcus aureus overtaken viridians group streptococci as the predominant etiological agent? Can. J. Infect. Dis. Med. Microbiol. 2008; 19: 63-68.

8. Palraj R.B., Baddour L.M., Hss P.E. i wsp. Predicting risk of endocarditis using a clinical tool (PREDICT): scoring system to guide use of echocardiography in the management of Staphylococcus aureus bacteremia. Clin. Infect. Dis. 2015; 61: 18-28.

9. Grupa Robocza Europejskiego Towarzystwa Kardiologicznego (ESC) do spraw zapobiegania, rozpoznawania i leczenia infekcyjnego zapalenia wsierdzia. Wytyczne dotyczące zapobiegania, rozpoznawania i leczenia infekcyjnego zapalenia wsierdzia (nowa wersja - 2009). Kardiol. Pol. 2010; 68 (supl. 1): S1-S52.

10. Falcone M., Russo A., Venditti M. Optimizing antibiotic therapy of bacteremia and endocarditis due to staphylococci and enterococci: New insights and evidence from the literature. J. Infect. Chemother. 2015; 21: 330-339. 